exists. In the accompanying table, the experimental values of the Hall coefficient $R$ for superconductors at room temperatures are recorded. In the last column the products $R_{\sigma}$ (where $\sigma$ is the conductivity at the same temperature) are given; the figures here are not very precise, because the corresponding quantities were not always measured on the same sample. We include in this table similar data for a lead-bismuth alloy ( 20 per cent bismuth) investigated recently in this laboratory.

\begin{tabular}{|c|c|c|c|c|}
\hline & & $\begin{array}{l}\text { Transition } \\
\text { point. }\end{array}$ & $R \times 10^{5}$ & $R \sigma$ \\
\hline 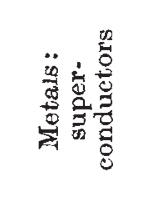 & $\begin{array}{l}\mathrm{Hg} \\
\text { (solid) } \\
\mathrm{Sn} \\
\mathrm{Pb} \\
\mathrm{In} \\
\mathrm{Tl} \\
\mathrm{Ta}\end{array}$ & $\begin{array}{l}4 \cdot 22 \\
3 \cdot 71 \\
7 \cdot 2 \\
3 \cdot 37 \\
2 \cdot 37 \\
4 \cdot 4\end{array}$ & $\begin{array}{c}<2 \\
2 \\
9 \\
7 \cdot 3 \\
24 \\
100(?)\end{array}$ & $\begin{array}{l}<1 \\
15 \cdot 3 \\
4.5 \\
8 \cdot 4 \\
13 \cdot 6 \\
60 \cdot 0(?)\end{array}$ \\
\hline 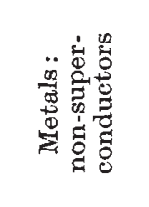 & $\begin{array}{l}\mathrm{Na} \\
\mathrm{Cu} \\
\mathrm{Ag} \\
\mathrm{Au} \\
\mathrm{Mg} \\
\mathrm{Zn} \\
\mathrm{W}\end{array}$ & & $\begin{array}{r}250 \\
52 \\
80 \\
70 \\
90 \\
104 \\
118\end{array}$ & $\begin{array}{l}550 \\
320 \\
536 \\
315 \\
207 \\
181 \\
225\end{array}$ \\
\hline $\begin{array}{l}\text { Supercon- } \\
\text { ductor }\end{array}$ & $\begin{array}{c}\mathrm{Pb}-\mathrm{Bi} \\
(20 \% \mathrm{Bi})\end{array}$ & & $<20$ & $<5$ \\
\hline 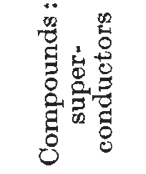 & $\begin{array}{l}\mathrm{CuS} \\
\mathrm{PbS}\end{array}$ & $\begin{array}{l}1 \cdot 6 \\
4 \cdot 1\end{array}$ & $\begin{array}{r}<100 \\
800\end{array}$ & $\begin{array}{l}<30 \\
8.5\end{array}$ \\
\hline 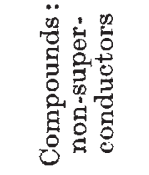 & $\begin{array}{l}\mathrm{Mo}_{2} \mathrm{~S} \\
\mathrm{Ag}_{2} \mathrm{~S}\end{array}$ & & $\begin{array}{c}2 \cdot 6 \times 10^{8} \\
0 \cdot 6.50 \times 10^{5}\end{array}$ & $\begin{array}{c}1400 \\
50-275\end{array}$ \\
\hline
\end{tabular}

As can be seen from these data, the superconductors show usually a relatively small value of $R$ and especially of $R \sigma$.

We are investigating now the validity of this rule for other superconductors. We reserve the discussion of the figures given in this note and the consideration of the theoretical conclusions which follow from this correlation for a detailed account which will be published soon in a new periodical entitled The Physics of the Soviet Union.

We have to thank Dr. Dorfman for his helpful discussion of our work.

I. KIKOIN.

BORIS LASAREW.

Magnetic Department,

Physical-Technical Institute,

Sosnovka 2, Leningrad (21).

Phys. Zeit., 4, 551 ; 1913.

2 Phil. Mag., 6, 1283; 1928.

Phys. Rev. (2), 1, 339 ; 1913

- Meissner, Zeit. für Phys., 58, 570; 1930 5 K. Fischbeck und O. Dorner, Zeit. für anorg. und alg. Chemie, 181,
372 , 1929 .

\section{Reactions of Horizons in Tropical Soils.}

THE reactions of a large number of samples carefully taken at different depths in the profiles of red soils which cover such large areas of south-central Africa have been determined in this laboratory. When the $p H$ values of samples taken from a pit dug in undisturbed virgin soil are plotted against the depth, almost perfect curves are invariably obtained, there being generally a depth of from two to three feet at which the maximum acidity is obtained. This is generally coincident with the depth at which there is a tendency to form a pan both in lateritic, true red, and immature red loams, and also in the ferruginous red loams described by Marbut and Shantz. In the latter soils, indeed, the pan is associated with definite concretions of hydrated sesquioxides.

Further results with samples from older cultivated lands generally show the highest point of acidity to be much nearer the surface. This is not surprising when the erosivity of red loam soils is considered and that often a quarter of an inch of soil has been removed in a

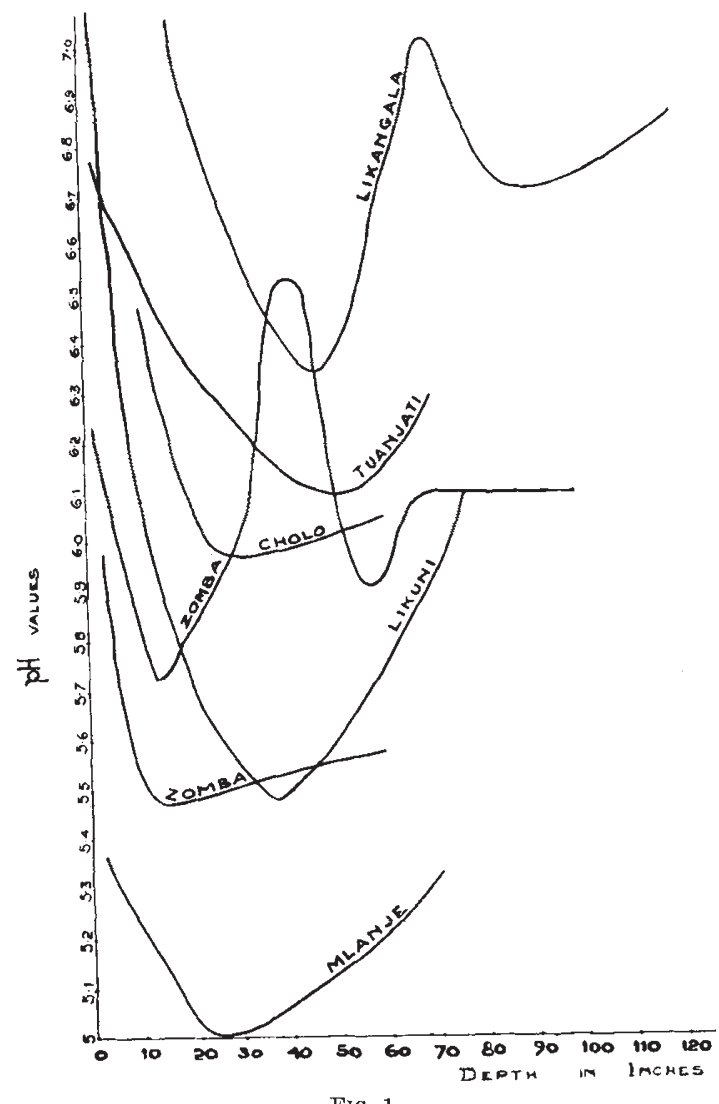

season by surface run-off and collected in large pits in Nyasaland.

There has been found in these studies a general correlation between $p \mathrm{H}$ values and figures for average rainfall, the highest acidity being found in the tea belt of Mlanje.

It has been further noticed in lower horizons of certain soils that a second point of maximum acidity is reached. This may, however, be associated with abnormal movement of underground water during the wet season.

It is suggested that these studies have a distinct bearing on the accumulation of compounds of iron, alumina, and manganese at certain horizons in tropical soils. There are strong indications that iron bacteria play an important part in the movements of such compounds and in the formation of pans.

A. J. W. HornBy,

Asst. Director of Agriculture, and Agricuitural Chemist.

Department of Agriculture, Zomba, Nyasaland, Nov. 4.

No. 3245, VoL. 129] 